\title{
A thief can't pass good title
}

\section{Tijdsverloop en eigendomsverkrijging naar civil en naar common law}

\author{
Prof. mr. E.J.H. Schrage*
}

\section{De ratio van de extinctieve verjaring}

Zowel in de rechtsstelsels die wortelen in het Romeinse recht, de civil law, als in de in Engeland ontstane en vandaar over de gehele Engelssprekende wereld verbreide common law doet van oudsher tijdsverloop rechten ontstaan of verloren gaan dan wel verbintenissen tenietgaan. De ratio daarachter is tweeerlei: enerzijds worden crediteuren of andere rechthebbenden aangespoord om op straffe van verjaring hun vorderingen te innen of hun recht in te roepen. Als een crediteur nalatig is zijn vermogensbestanddelen te beschermen, dan moet het hem niet verbazen als op zeker moment zijn rechtsbescherming teloor is gegaan. Zoals Oliver Wendell Holmes, Jr. het zo'n honderd jaar geleden welsprekend formuleerde: 'Sometimes it is said that, if a man neglects to enforce his rights, he cannot complain if, after a while, the law follows his example.' Anderzijds betekent voor de debiteur of de bezitter het intreden van de verjaring, hetzij de extinctieve, hetzij de acquisitieve, een zekere bescherming tegen vorderingen die te lang op een plank zijn blijven liggen verstoffen, zodat (de bewijsmiddelen voor) mogelijk op te werpen verweren verloren zijn gegaan. In de traditie van de common law is deze ratio achter het instituut van de verjaring al neergelegd in de Amerikaanse beslissing van Riddlesbarger v Hartford Insurance Company, 74 U.S. 386, 390 (1868):

'[Statutes of limitations] are founded upon the general experience of mankind that claims which are valid are not usually allowed to remain neglected. The lapse of years without any attempt to enforce a demand creates, therefore, a presumption against its original validity, or that it has ceased to subsist. This presumption is made by these statutes a positive bar; and they thus become statutes of repose, protecting parties from the prosecution of stale claims, when, by loss of evidence from death of some witnesses, and the imperfect recollection of others, or the destruction of documents, it might be impossible to establish the truth.'

Verjaring bevordert voortvarend handelsverkeer. Een rechtsvordering moet niet op de wijze van het zwaard van Damocles blijven hangen boven het hoofd van een mogelijke gedaagde. Verwaarlozing van rechten wordt gestraft met het verlies van de rechtsvordering. Het is in strijd met de zorgvuldigheid die in het maatschappelijk verkeer betaamt om, na eerst de vaste indruk te hebben gewekt de vordering niet meer geldend te zullen maken (of het recht niet meer geldend te zullen maken), na verloop van lange tijd te pogen alsnog de wederpartij in rechte te betrekken. Zo bezien liggen verjaring en rechtsverwerking in elkaars verlengde en het is al een oud beginsel dat het verlies gedragen moet worden door degene die het verlies ook door zijn handelen of nalaten heeft veroorzaakt.

\section{De relatie tussen extinctieve en acquisitieve verjaring: dief wordt eigenaar}

Verwant aan de extinctieve verjaring van vorderingsrechten is het verloren gaan van rechten door de rechthebbende en de verkrijging ervan door degene die langjarig het gebruik ervan maakte. De relatie tussen het verloren gaan van het vorderingsrecht en de verkrijging van het recht door degene die dat recht gedurende lange tijd heeft uitgeoefend, is lang niet altijd duidelijk. Onder de vigeur van het Burgerlijk Wetboek (BW) van 1838 was de positie van de eigenaar, wiens revindicatie was verjaard, op zijn minst genomen onhelder. Men placht die positie met de historische term dominium sine re (eigendom zonder zaak) aan te duiden. Naar geldend recht impliceert echter het verval van de revindicatie de aanwas van de eigendom bij de bezitter van de zaak (art. 3:105 BW).

Het was de keuze van de wetgever om een beroep op eigendomsverkrijging als bedoeld in art. 3:314 lid 2 BW in verbinding met art. 3:105 lid $1 \mathrm{BW}$ niet te ontzeggen aan de partij zelf die te kwader trouw de zaak in bezit heeft genomen. Aan die keuze ligt niet een afweging ten grondslag van de tegenover elkaar staande belangen van de rechthebbende en die bezitter (zoals dat wel het geval is bij de verjaring ten gunste van een bezitter te goeder trouw (art. 3:99 BW)). Art. 3:105 BW is uitsluitend ingegeven door de wens dat, als geen vordering meer kan worden ingesteld om het bezit te beëindigen, de

Prof. mr. E.J.H. Schrage is Honorary Professor aan de Nelson Mandela University te Port Elizabeth (South Africa) en emeritus hoogleraar privaatrecht aan de Universiteit van Amsterdam.

1. O.W. Holmes, Jr., The Path of the Law, Harvard Law Review (10) 1879 , p. 476. 
bezitter eigenaar wordt, ook al staat zijn goede trouw niet vast. $^{2}$

'Dief wordt eigenaar', zo vatte Brunner kort na de invoering van het BW van 1992 het door de wetgever verkozen systeem kernachtig samen. ${ }^{3}$ De wetgever liet zich bij deze keuze inspireren door de Zweite Kommission, die bij de voorbereiding van het Duitse BGB tot de slotsom was gekomen dat het uit het Romeinse recht stammende systeem van een na de extinctieve verjaring van de terugvorderingsactie van de eigenaar (de revindicatie) bij de werkelijk rechthebbende achterblijvend eigendomsrecht zonder rechtsvordering een ongewenste toestand was. Dus wenste de wetgever dit dominium sine re zo veel mogelijk terug te dringen. ${ }^{4}$ Meijers kwalificeerde dit dominium sine re zelfs als een anomalie. ${ }^{5}$

De in artikel 3:105 BW bedoelde verjaringstermijn bedraagt in beginsel twintig jaar (art. 3:306 BW). De termijn van verjaring van een rechtsvordering strekkende tot beëindiging van het bezit van een niet-rechthebbende begint met de aanvang van de dag, volgende op die waarop een niet-rechthebbende bezitter is geworden of de onmiddellijke opheffing gevorderd kon worden van de toestand waarvan diens bezit de voortzetting vormt, aldus art. 3:314 lid 2 BW. Deze bepaling vormt slechts een toepassing van het eerste lid van art. 3:314 BW, waarin bepaald wordt dat de verjaringstermijn van een rechtsvordering tot opheffing van een onrechtmatige toestand - als hoedanig ook het bezit van een niet-rechthebbende valt aan te merken - begint met de aanvang van de dag, volgende op die waarop de onmiddellijke opheffing van die toestand gevorderd kan worden. ${ }^{6}$ Kortom: voldoende en noodzakelijke voorwaarde is dat een ander dan de oorspronkelijk rechthebbende (en dat hoeft niet steeds dezelfde te zijn geweest: de tijd van zijn rechtsvoorganger mag de bezitter bij de zijne optellen: accessio

2. Aldus r.o. 3.7.2 van HR 24 februari 2017, ECLI:NL:HR:2017:309, AAe 2017, p. 516 m.nt. A.G. Castermans, JOR 2017/186 m.nt. S.E. Bartels en V. Tweehuysen, VGR 2017, p. 69 m.nt. R.L. Fabritius, BR 2017/80 m.nt. K. Meijering en I.L.M.W. Theunisse, Gst. 2017/77 m.nt. W. Lever, NJ 2018/141 m.nt. H.J. Snijders (Gemeente Heusden/Verweerders). De onderhavige paragraaf leunt sterk op de conclusie van A-G E.B. RankBerenschot voor dit arrest.

3. C.J.H. Brunner, Dief wordt eigenaar, in: E.H. Hondius, W.G. Huijgen, Jac. Hijma e.a. (red.), Quod licet (Kleijn-bundel), Deventer: Kluwer 1992, p. 45-53. Voor een overzicht van de nadien verschenen Nederlandse literatuur, zie T. van der Linden, Over de dief die eigenaar geworden is, in: W.H. van Boom (red.), Een kwart eeuw: privaatrechtelijke opstellen, aangeboden aan prof. mr. H.J. Snijders ter gelegenheid van zijn emeritaat, Deventer: Wolters Kluwer 2016, p. 291-305.

4. Th. Finkenauer, Eigentum und Zeitablauf - das dominium sine re im Grundstücksrecht, zugleich ein Beitrag zur Entstehungsgeschichte des BGB (Schriften zum Bürgerlichen Recht 238), Berlijn: Duncker und Humblot 2000.

5. Aan deze keuze van de wetgever ligt wat betreft art. 3:105 BW ten grondslag dat in het ontwerp van het BW is 'gebroken met de [destijds] bestaande anomalie, dat de werkelijke rechthebbende de zaak niet kan opvorderen en anderzijds de bezitter in zijn bezit beschermd wordt, maar met niet meer dan bezitsacties. Het recht dient zich op den duur bij de feiten aan te sluiten, vooral wanneer dit recht de nodige rechtsvorderingen om wijziging te brengen in de feitelijke verhoudingen aan de rechthebbende onthoudt' (Parl. Gesch. Boek 3, p. 416).

6. MvA II, Parl. Gesch. Boek 3, p. 931 temporis) gedurende twintig jaar of langer het bezit heeft gehad.

Blijft dan nog de vraag wat in dat verband bezit is. Die vraag moet worden beantwoord aan de hand van de maatstaven van art. 3:107 e.v. BW. Het gaat om wat de Duitsers Eigenbesitz plegen te noemen: het uitoefenen van de feitelijke macht over een goed (corpus) met de pretentie (animus possidendi) daarvan eigenaar te zijn. Die animus possidendi moet kenbaar zijn uit bezitsdaden, paradoxaal genoeg dus daden die de pretentie eigenaar te zijn verraden. Dat betekent dat uit die daden de pretentie tot exclusiviteit moet blijken, dat wil zeggen de bedoeling om anderen, ook de gedepossedeerde eigenaar, het gebruik van dat goed te ontzeggen. ${ }^{7}$ In de terminologie van het BW van 1838 (art. 1992) moest dat bezit ondubbelzinnig en openbaar zijn, ${ }^{8}$ twee criteria die ook onder het nieuwe recht hun geldigheid hebben behouden. ${ }^{?}$

In beginsel wordt dat bezit verkregen door occupatie (gaat het om een res nullius, dan impliceert die occupatie eigendomsverkrijging), door overdracht op de juiste manier (geschiedt die door een beschikkingsbevoegde anders dan om niet, dan brengt die overdracht eigendomsverkrijging met zich) of door opvolging onder algemene titel, aldus art. 3:112 BW. Uit art. 3:313 BW leidt de Hoge Raad dan af dat de opvolgende bezitter slechts dan het bezit kan verkrijgen als de vorige bezitter het heeft verloren:

'Voor de beantwoording van de vraag of iemand een zaak in bezit heeft genomen, is bepalend of hij de feitelijke macht over die zaak is gaan uitoefenen (art. 3:113 lid 1 $\mathrm{BW}$ ). Indien de zaak in het bezit van een ander is, zijn enkele op zichzelf staande machtsuitoefeningen voor inbezitneming onvoldoende (art. 3:113 lid 2 BW). De machtsuitoefening moet derhalve zodanig zijn dat deze naar verkeersopvatting het bezit van de oorspronkelijke bezitter teniet doet (Parl. Gesch. Boek 3, p. 434). Het antwoord op de vraag of iemand de voor bezit vereiste feitelijke macht uitoefent wordt, evenals de vraag of hij voor zichzelf of voor een ander houdt, bepaald naar verkeersopvatting en overigens op grond van uiterlijke feiten (art. 3:108 BW). ${ }^{\cdot 10}$

De consequentie van een en ander is duidelijk: het was de keuze van de wetgever om een beroep op eigendomsverkrijging als

7. Aldus reeds expliciet MvA II, Parl. Gesch. Boek 3, p. 434-435: 'De machtsuitoefening van de inbezitnemer moet die van de oorspronkelijke bezitter teniet doen; eerst dan staat deze machtsuitoefening niet meer op zichzelf. (...) Beperkt iemands machtsuitoefening over andermans fiets zich ertoe dat hij daarop eens of meermalen zonder diens toestemming rijdt, dan doet dit op zichzelf het bezit van die ander nog niet teniet.'

8. HR 7 maart 1980, ECLI:NL:HR:1980:AB7496, NJ 1980/549 m.nt. WMK (Schellekens/Braam).

9. Zie vooral de conclusie van A-G mr. E.B. Rank-Berenschot voor HR 24 februari 2017, ECLI:NL:HR:2017:309, NJ 2018/141 m.nt. H.J. Snijders (Gemeente Heusden/Verweerders), onder 2.2.7 en 2.7 voor rechtspraak, parlementaire geschiedenis en overige literatuur.

10. HR 18 september 2015, ECLI:NL:HR:2015:2743, NJ 2016/78 m.nt. F.M.J. Verstijlen (Vogelzang/Landgraf), r.o. 3.4.2. 
bedoeld in art. 3:314 lid $2 \mathrm{BW}$ in verbinding met art. 3:105 lid $1 \mathrm{BW}$ niet te ontzeggen aan de bezitter, zelfs niet als die partij zelf te kwader trouw de zaak in bezit heeft genomen.

\section{Dief wordt eigenaar, maar niet naar common law}

Deze keuze van de (Duitse en de Nederlandse) wetgever vond en vindt in de common law echter weinig tot geen bijval. Eerst was het de Engelse rechter Mr Moses J., die in City of Gotha v Cobert Finance S.A. stelde ${ }^{11}$ dat naar Engelse opvatting een systeem waarin de dief eigenaar kan worden, in strijd met de Engelse openbare orde moet worden geoordeeld, en onlangs volgde de hoogste rechter van New York dit voorbeeld in de zaak Bakalar v Vavra. ${ }^{12}$ Het Duitse en het Nederlandse verjaringsrecht in strijd met de Engelse en de Amerikaanse openbare orde! Het is een heel fors oordeel, stoelend op de gedachte van de Court of Appeals for the Second Circuit in zijn uitspraak van 2 september 2010, dat de plaats waar dat recht (een stelsel als het Nederlandse) wordt toegepast noodzakelijkerwijs 'become[s] a marketplace for stolen goods and, in particular, for stolen artwork'. Zoiets moet je niet willen, vindt men in de landen van de common law. Dat doet de vraag rijzen hoe de common law dan wel vindt dat het verjaringsrecht moet luiden in geval van onvrijwillig bezitsverlies door de oorspronkelijk rechthebbende. Centraal bij die vraag staat het moment waarop de verjaring begint te lopen. Er zijn daar verschillende mogelijkheden denkbaar: (1) het moment van de diefstal, (2) het moment van de verkrijging door de actuele bezitter (de aanvang van de adverse possession), dan wel (3) het moment waarop de bestolene bekend is met het feit dat hij een rechtsvordering heeft en tegen wie hij die moet instellen (discoverability test), of (4) zelfs nog later, zoals te zien is in het recht van New York. Die staat legt het moment waarop de extinctieve verjaring van de revindicatie aanvangt in handen van de (oorspronkelijk) rechthebbende. Eerst als hij zijn goed heeft teruggevraagd van de bezitter en deze afgifte heeft geweigerd, begint de verjaring te lopen. Men pleegt in dit verband van de demand-and-refusal rule te spreken.

Ik zal eerst een aantal belangrijke uitspraken waarin die regel beslissend was voor de uitkomst van het geding aan de orde stellen (par. 4). Vervolgens zal ik een aantal opmerkingen maken naar aanleiding van het al geciteerde arrest inzake de Gemeente Heusden tegen verweerders (par. 5), om mij ten slotte af te vragen of van convergentie van het Nederlandse recht met de common law sprake kan zijn (par. 6).

\section{Demand-and-refusal rule}

In het belangenconflict tussen de oorspronkelijk rechthebbende die zijn goed onvrijwillig heeft verloren enerzijds en de verkrijger ervan te goeder trouw anderzijds zijn eigenlijk elk van

11. High Court (England and Wales), 9 september 1998, City of Gotha and Federal Republic of Germany v Sotheby's and Cobert Finance S.A., toegankelijk via https://germanlawarchive.iuscomp.org/?p=956.

12. Bakalar v Vavra, 550 F. Supp. 2d 548 (S.D.N.Y. 2008); 619 F.3d 136 (2d Cir. 2010); 819 F. Supp. 2d 293 (S.D.N.Y. 2011); 11-4042-cv (2d Cir. 2012). de partijen evenzeer slachtoffer, namelijk slachtoffer van een en dezelfde dief. Met dat gegeven in het achterhoofd ziet de rechter zich dus voor de vraag gesteld wie van die twee slachtoffers meer de bescherming verdient die het privaatrecht kan geven: de gedepossedeerde eigenaar of de verkrijger te goeder trouw? De common law is aanzienlijk meer dan de continentaal-Europese rechtsstelsels geneigd om de oorspronkelijke eigenaar te beschermen, terwijl de civil law geneigd is om de prioriteit te leggen bij de bescherming van de belangen van het handelsverkeer, zodat de verkrijger te goeder trouw dikwijls aan het langste eind trekt. Het verschil tussen beide rechtsstelsels werd onlangs nog eens verwoord door de (toen nog) US Special Envoy for Holocaust Issues, Douglas Davidson, die de aandacht vroeg voor

'a provision in American law not common in continental European legal systems - the idea that a stolen good is always just that. Unlike in civil systems, in the US good faith purchasers cannot wait years and then know that their hold on what turns out to be a stolen good is secure. As American lawyers like to say: nemo dat quod non habet ("No one gives what he does not have") or, more colloquially: "A thief can't pass good title."'13

Waar het Nederlandse recht de koper te goeder trouw van een roerend goed die is afgegaan (en mocht afgaan) op het door de rechtsvoorganger uitgeoefend bezit een adequate rechtstitel geeft (possession vaut titre zegt art. 2276 van de Code civil), verkrijgt de koper naar Amerikaans recht geen titel. Dat betekent nog niet dat sprake zou zijn van onrechtmatig bezit. Die kwalificatie komt pas aan de orde als de eigenaar zijn zaak heeft teruggevorderd en de koper geweigerd heeft op die sommatie in te gaan. De common law beschouwt het zonder toestemming gebruiken van andermans goed, als ware het eigen goed (conversion), als een onrechtmatige daad (tort), maar de delictsomschrijving van die onrechtmatige daad wordt eerst vervuld wanneer de gebruiker opzet te verwijten valt en de rechthebbende door die conversion schade lijdt. Dat geval doet zich pas voor indien de gebruiker zich op vordering van de rechthebbende weigerachtig toont tot restitutie over te gaan. Deze regeling staat bekend onder de naam demand-andrefusal rule. Pas na de weigering het goed terug te geven kan de rechthebbende de evenknie van de op het Romeinse recht teruggaande revindicatie, replevin, en/of de actie uit conversion instellen. De verjaringstermijn voor deze acties begint eerst te lopen op het moment waarop de bezitter de restitutie weigert.

\subsection{Demand-and-refusal rule - het begin}

In Gillet v Roberts, 57 N.Y. 28 (1874) had een zekere Dennis hout gekapt van het land van Gillet en dat via de Cowanesquerivier stroomafwaarts laten drijven. Het hout bereikte zijn bestemming niet, want Dennis had nog openstaande boetes en

13. D. Davidson, Just and Fair Solutions. A View from the United States, in: E. Campfens (red.), Fair and Just Solutions? Alternatives to Litigation in Nazi-looted Art Disputes: Status Quo and New Developments, Den Haag: Eleven International Publishing 2015, p. 100. 
de oplettende sheriff van Tioga County, Pennsylvania vond hier een mogelijkheid om die te innen. Hij nam het hout in beslag en verkocht dat bij wege van executie van die boetes aan Swineley, die het hout doorverkocht aan Roberts. Aangesproken door Gillet toonde Roberts zich bereid tot afgifte van het hout op de door Gillet aangewezen plaats op de oever van de rivier, maar dan wel tegen vergoeding van zijn kosten. Gillet weigerde echter betaling daarvan en verwees Roberts naar diens rechtsvoorganger, Swineley. Voordat dat meningsverschil was beslecht, stak een storm op, en die sloeg het hout los. Wie zal dat betalen? Robert Earl J. overwoog dat van de onrechtmatige daad van conversion eerst sprake is wanneer hij de mogelijkheid tot teruggave uitdrukkelijk heeft geweigerd te gebruiken:

'The rule is a reasonable and just one, that an innocent purchaser of personal property from a wrong-doer shall first be informed of the defect in his title, and have an opportunity to deliver the property to the true owner, before he shall be made liable as a tortfeasor for a wrongful conversion.'

Daarmee had de demand-and-refusal rule de status van precedent in het recht van New York verworven.

\subsection{Demand-and-refusal rule - enige rechtspraak}

Dat bleek uit een van de standaardarresten over teruggave van roofkunst: Menzel v List. ${ }^{14} \mathrm{Bij}$ hun vlucht voor de nazi’s uit Brussel in 1941 lieten de Menzels noodgedwongen een schilderij van Marc Chagall achter. Zij vestigden zich in de Verenigde Staten en hun speurtocht naar het schilderij werd in 1962 met succes bekroond: zij troffen het aan bij List. In rechte betrokken wierp List het verjaringsverweer op (de termijn van de extinctieve verjaring bedraagt in New York drie jaar), maar dat werd verworpen met een beroep op Gillet v Roberts: de verjaring van de vordering (replevin) begint niet op het moment van de diefstal of van de verkrijging door de actuele bezitter, maar eerst op het moment dat deze op het verzoek tot afgifte afwijzend antwoordt. Tot op dat moment is

'the innocent purchaser's possession (...) not wrongful or unlawful. Having acquired the property honestly, the innocent purchaser does no wrong by merely retaining possession, for until the demand and refusal he has no notice of the claim of anyone else.'

Er kleeft echter een duidelijk nadeel aan de demand-andrefusal rule in zijn zuivere vorm en dat is dat die regel het begin van de verjaringstermijn volledig in handen van de gedepossedeerde eigenaar legt: zolang hij niet claimt, loopt de verjaring niet. Daarmee is het risico van opportunistische chicanes gege-

14. 253 N.Y.S.2d 43 (App. Div. 1964); 267 N.Y.S.2d 804 (Sup. Ct. 1966); 279 N.Y.S.2d 608 (App. Div. 1967); 246 N.E.2d 742 (N.Y. 1969). ven. ${ }^{15}$ Langzaam is dan ook in de rechtspraak in New York een soort due diligence-vereiste aan het eigen optreden van de eiser tot wasdom gekomen: de eiser moet wel voldoende naspeuringen hebben verricht. Die eis werd nog niet met zoveel woorden gesteld in Kunstsammlungen zu Weimar v Elicofon, ${ }^{16}$ maar een eerste aanzet werd wel gegeven. Elicofon had in 1946 voor de prijs van \$ 450 twee schilderijen van Albrecht Dürer gekocht van een Amerikaanse soldaat. Ze hadden twintig jaar bij hem aan de muur gehangen totdat het museum ze ontdekte en terugvorderde. Het verjaringsverweer van Elicofon werd gepasseerd, ${ }^{17}$ evenals het laches-verweer, het (equitable) verweer dat het museum te weinig inspanningen had verricht en te veel tijd had laten verlopen om nog met goed fatsoen de schilderijen te kunnen opeisen. ${ }^{18}$ De Court of Appeals liet uitdrukkelijk in het midden of het recht van New York een dergelijk verweer (er)kent, maar reeds bij gebrek aan feitelijke grondslag kon het Elicofon niet baten. In het belangenconflict tussen de gedepossedeerde eigenaar die niet weet waar en tegen wie zijn vordering in te stellen enerzijds en de verkrijger te goeder trouw die lange jaren bezitter was, kiest New York uitdrukkelijk voor de eerste en wel door de verjaring eerst te laten aanvangen bij de weigering tot restitutie:

'As between the policy (...), of allowing the statute of limitations to run against an owner regardless of his ignorance, and tolling it indefinitely against a good-faith purchaser until a demand is made, we are satisfied that New York has chosen the latter.' ${ }^{\prime 9}$

Even later, in DeWeerth v Baldinger, ${ }^{20}$ leek echter het roer om te gaan: daar werd door de feitelijke instanties het bestaan van een onderzoeksplicht voor de gedepossedeerde eigenaar aangenomen en in hoger beroep het verrichte onderzoek door de hoogbejaarde mevrouw DeWeerth als te mager gekwalificeerd, zodat haar vordering werd afgewezen. Deze uitspraak bereikte echter niet de status van precedent; in het in het laatste decennium van de vorige eeuw gewezen standaardarrest Guggenheim Foundation v Lubell ${ }^{21}$ nam de New York Court of Appeals met zoveel woorden afstand van de beslissing van het

15. A. Hawkins, R.A. Rothman \& D.B. Goldstein, A Tale of Two Innocents: Creating an Equitable Balance Between the Rights of Former Owners and Good Faith Purchasers of Stolen Art, Fordham Law Review (64) 1995, afl. 1, p. 49-96.

16. 678 F.2d 1150 (2d Cir. 1982). Zie B.L. Hay, Nazi-looted Art and the Law. The American Cases, Boston: Springer 2017, p. 166 e.v.

17. '[The Menzel decision had applied] these principles to a case involving a bona fide purchaser of stolen art works, holding that the cause of action accrues only after demand and refusal'; 678 F.2d $1150 \$ 1163$.

18. Het woord laches stamt van het middeleeuwse lachesse, dat op zijn beurt uit het Lawfrench stamt als laschesce, dat teruggaat op het Latijnse lax of laxare. Het laches-verweer vertoont veel gelijkenis met het verweer van rechtsverwerking naar Nederlands recht. In beide gevallen is het enkele tijdsverloop onvoldoende om de vordering te verlammen; er moet iets bij komen, meestal dat de gedaagde vanwege het handelen en nalaten van de eiser erop mocht vertrouwen dat die zijn vordering niet meer zou instellen en op grond van dat vertrouwen heeft gehandeld.

19. 678 F.2d 1163-64.

20. 836 F.2d 103 (2d Cir. 1987), cassatieberoep (certiorari) geweigerd, 486 U.S. 1056 (1988). Hay 2017, p. 168-169.

21. Solomon R. Guggenheim Foundation v Lubell, 569 N.E. 2 d 426 (1991). 
Second Circuit inzake DeWeerth v Baldinger. De demandand-refusal rule geeft de eigenaar een grote mate van bescherming en is daarom goed en in overeenstemming met het recht van New York. De nadruk op (het ontbreken van) due diligence bij de oorspronkelijke eigenaar is bovendien uiterst eenzijdig. Ook de door de koper verrichte inspanningen te achterhalen of de verkoper wel beschikkingsbevoegd is en het door hem verrichte provenance-onderzoek zouden minstens in de belangenafweging moeten worden betrokken. In de zaak van het Guggenheim Museum ging het om een gouache van Chagall, getiteld Le marchand de bestiaux, dat het museum in 1937 zou hebben verkregen en behouden, totdat het in 1965 intern als vermist werd aangemerkt. In 1967 kocht Lubell het van de Robert Elkon Gallery, een te goeder naam en faam bekendstaande kunsthandelaar. Hij leende het werk twee keer uit voor openbare tentoonstellingen, maar tijdens een taxatie door Sotheby's herkende de desbetreffende employee (die voorheen in het Guggenheim Museum werkzaam was geweest) de gouache als de vermiste Chagall. In eerste aanleg werd de vordering van het Guggenheim Museum tot teruggave van het werk afgewezen: het museum had uit overwegingen van public relations de zoektocht beperkt tot de eigen gebouwen en niet buiten de deur gekeken. Dat was onvoldoende, vond de trial court, om de door Lubell opgeworpen verweren, een beroep op de verjaringstermijn van drie jaar van het recht van New York, subsidiair het laches-verweer, te overtroeven. Dat oordeel vond reeds vanwege de eenzijdige nadruk op de (in)activiteit van het museum geen genade in de ogen van de appellate division, noch in die van de Court of Appeals: het had op de weg van de koper gelegen om (al was het maar) enig onderzoek naar de provenance van het werk te doen. Had hij alleen maar de oeuvrecatalogus van Chagall geraadpleegd, dan had hij kunnen zien dat het werk in het Guggenheim Museum thuishoorde.

\subsection{Demand-and-refusal rule-op zoek naar een nieuwe belangenafweging}

Daarmee is de toon gezet: in het belangenconflict tussen de gedepossedeerde eigenaar en de bezitter, zeker de bezitter te goeder trouw, valt de belangenafweging in beginsel uit in het voordeel van de eerste; het omgekeerde zou New York tot een paradijs voor dieven maken. Dat uitgangspunt is echter vervolgens voorwerp van rechtsverfijning. Een verwijtbare inactiviteit aan de zijde van de eigenaar (laches) kan ertoe leiden dat zijn vordering wordt afgewezen. Dat moesten ook de erven Mauthner ervaren (overigens in een zaak die naar het recht van California werd beslecht), toen zij poogden Liz Taylor te bewegen tot afgifte aan hen van Vue de l'asile et de la Chapelle de Saint-Rémy, een schilderij dat Vincent van Gogh een jaar voor zijn zelfgekozen dood had gemaakt en dat Margareth Mauthner bij haar vlucht voor de nazi's had moeten achterlaten in Duitsland. Francis Taylor had het schilderij op een veiling bij Sotheby's in Londen in 1969 gekocht en het aan zijn dochter geschonken. Een en ander was met veel publiciteit omgeven geweest. Liz Taylor had het schilderij ook nog eens voor tentoonstellingen afgestaan. Onder die omstandigheden veertig jaar zonder dwingende reden wachten met het indienen van de vordering is onvergeeflijk. Die vordering wordt de eigenaar dan ook ontzegd. ${ }^{22}$

Het omgekeerde is echter evenzeer waar: een al te zorgeloze koper wordt op zijn beurt het verweer tegen de vordering van de eigenaar ontzegd. De onrechtmatige daad van de koper (conversion) is echter niet het feit dat hij zonder nader onderzoek van de provenance het goed van een ander heeft gekocht, evenmin het feit dat hij het gedurende langere tijd onder zich heeft gehouden, maar de onrechtmatige daad treedt eerst dan in wanneer hij na daartoe gesommeerd te zijn de afgifte van het goed aan de eigenaar weigert. De daarop stoelende vordering verjaart na ommekomst van drie jaar. Dat is de demand-and-refusal rule. ${ }^{23}$ Elisa B. Pollack heeft erop gewezen dat latere rechtspraak inderdaad de eenzijdige nadruk op de (on)zorgvuldigheid van het onderzoek van de vorige eigenaar heeft verlaten en tegenwoordig een meer evenwichtige belangenafweging zoekt, ${ }^{24}$ een stelling die zij staaft aan de hand van een drietal arresten, vooral de nieuwe landmark case Mirvish v Mott. ${ }^{25}$ Het ging hierom. Jacques Lichitz was beeldhouwer. Bij zijn dood (in 1973, op de leeftijd van 81 jaar) liet hij zijn vrouw Yulla onder meer een aantal beeldhouwwerken na. In 1980 begon Yulla een nieuwe relatie, met Biond Fury, met wie ze nog zeventien jaar zou samenleven, tot zij in 2003 overleed. In hun appartement stonden tal van kunstwerken vervaardigd door Jacques Lichitz. Daarvan schonk Yulla gedurende die zeventien jaar samenleving haar partner van tijd tot tijd een beeldhouwwerk. Ze documenteerde die schenking door achterop een foto het stuk te beschrijven en te verklaren dat het een schenking aan Biond Fury betrof. Er waren echter ook verscheidene stukken in consignatie gegeven aan een kunsthandelaar en bij deze opgeslagen. Daaronder was ook The Cry. Dat laatste moest ook wel, want het stuk was in ieder geval veel te groot en te zwaar (meer dan $500 \mathrm{~kg}$ ) om in het

22. Adler v Taylor, 2005 WL 4658511 (C.D. Cal. 2005); besproken door A. Chchi, A.L. Bandle \& M.-A. Renold, Case View of the Asylum and Chapel at St. Rémy - Mauthner Heirs v. Elizabeth Taylor, Platform ArThemis (http://unige.ch/art-adr), Art-Law Centre, University of Geneva (https://plone.unige.ch/art-adr/cases-affaires/case-view-of-the-asylumand-chapel-at-st-remy-2013-mauthner-heirs-v-elizabeth-taylor/casenote-2013-view-of-the-asylum-and-chapel-at-st-remy).

23. 'The rule in this State is that a cause of action for replevin (...) accrues when the true owner makes a demand for the return of the chattel and the person in possession of the chattel refuses to return it. (...) Until demand is made and refused, possession of the stolen property (...) is not considered wrongful.' Guggenheim, 77 N.Y.2d, $\$ 320$.

24. E.B. Pollack, Toward a New Standard in Art Recovery Cases: New York's Solomon R. Guggenheim Foundation v. Lubell and the Rejection of Due Diligence, Columbia-VLA Journal of Law \& the Arts (16) 1992, p. 361-379.

25. J. Wallace, New York's Distinctive Rule Regarding Recovery of Misappropriated Art after the Court of Appeals' Decision in Mirvish v Mott, Spencer's Art Law Journal (3) 2012, afl. 1, zie www.artnet.com/ magazineus/news/spencer/spencers-art-law-journal-7-18-12.asp, met een beroep op Hoelzer v City of Stamford, 933 F.2d 1131 (2d Cir. 1991); Golden Buddha Corp. v Canadian Land Co. of America, 931 F.2d 196 (2d Cir. 1991); Republic of Turkey v Metropolitan Museum of Art, 762 F. Supp.44 (S.D.N.Y. 1990); Mirvish v Mott, 18 N.Y.3d 510 (2012). Dit laatste arrest is ook toegankelijk via www.nycourts.gov/ctapps/ Decisions/2012/Feb12/5opn12.pdf. 
appartement neer te zetten. The Cry werd in 1998 door Hanno Mott, Yulla's zoon uit een eerdere relatie en haar vertegenwoordiger bij volmacht, in bruikleen gegeven aan het Louvre voor een tentoonstelling in de Jardin des Tuileries, een prachtig park in het centrum van Parijs tussen het Musée du Louvre en de Place de la Concorde. Na de dood van Yulla kwam haar partner, Fury, in actie. Hij sommeerde Mott zowel in persoon als in diens hoedanigheid van executeur-testamentair tot afgifte aan hem, Fury, van The Cry en hij legde een foto van The Cry over met op de achterzijde geschreven, onmiskenbaar in Yulla's handschrift: 'I gave this sculpture "The Cry" to my good friend Biond Fury in appreciation for all he did for me during my long illness. With love and my warm wishes for a Happy Future, Yulla Lipchitz October 2, 1997, New York.' Mott stelde zich echter op het standpunt The Cry tezamen met vier andere kunstwerken in juli 2004, een jaar na het overlijden van Yulla, te hebben verkocht aan de galeriehouder, die ze al in consignatie had. Fury verkocht daarop zijn rechtsvordering jegens de nalatenschap van Yulla en tegen Mott in privé aan Mirvish (vandaar de naam van de procespartijen: Mirvish v Mott).

Een procesovereenkomst tussen partijen bracht de zaak uiteindelijk voor de Court of Appeals, de hoogste rechter van de staat New York. Eigenlijk bleven maar twee vragen ter beantwoording over, namelijk (1) of The Cry daadwerkelijk door schenking uit het vermogen van Yulla was overgegaan in dat van Fury, en indien zo, (2) of diens rechtsvordering al dan niet na de bruikleenovereenkomst met het Louvre van 1998 (volgens Mott het moment van de wederrechtelijke toe-eigening, conversion, van de een jaar tevoren geschonken sculptuur) door verjaring teniet was gegaan. De eerste vraag bleek eenvoudig te beantwoorden. In Gruen v Gruen ${ }^{26}$ had de Court of Appeals al eens uitgemakkt dat een geldige schenking inter vivos veronderstelt de bevoordelingsbedoeling bij de schenker, een levering, en een aanvaarding door de begiftigde, en dat de bewijslast rust op degene die zich op de schenking beroept. In deze zaak leverde de foto met achterop de beschrijving van The Cry en de eigenhandige verklaring van Yulla dat het een schenking aan Fury betrof voldoende bewijs voor het aanbod en de aanvaarding van de schenking, alsmede voor de levering. De tweede vraag is daarmee eigenlijk ook al beantwoord. Fury was eigenaar geworden door schenking en levering. Dus was de nalatenschap nooit eigenaar geweest, en het verjaringsverweer van Mott stuit af op de procesovereenkomst in het licht van de demand-and-refusal rule.

\section{Nederlands recht}

Naar Nederlands gaan deze zaken geheel anders. Daarbij is allereerst van belang dat de bijzondere regeling van art. 3:86 BW de overdracht van een roerende zaak niettegenstaande de onbevoegdheid van de vervreemder geldig verklaart, mits de verkrijger te goeder trouw is en de overdracht anders dan om niet geschiedt, met dien verstande dat in geval van diefstal de

26. Gruen v Gruen, 68 N.Y.2d 48 [1986]. gedepossedeerde eigenaar nog gedurende drie jaar te rekenen vanaf de dag van de diefstal zijn zaak kan revindiceren. Weliswaar kan volgens art. 3:86a en 3:86b BW dit artikel niet worden tegengeworpen aan staten die op onrechtmatige wijze buiten hun territorium gebrachte cultuurgoederen terugvorderen, maar dit neemt niet weg dat oorspronkelijke eigenaren van roerende zaken slechts zelden aan de algemene verjaringsregeling van art. 3:306 BW zullen toekomen. Toch kan dat wel. Dat leert de volgende zaak.

\subsection{Het Land Sachsen tegen Cohen}

Het staat wel vast dat het Russische leger op zijn terugtocht in 1945 de Gemäldegalerie te Dresden grondig geplunderd heeft. Onder meer verdween een schilderij van Jan van der Heyden, getiteld Klooster in landschap. Het Land Sachsen, eigenaar van het schilderij, heeft kort na de oorlog een lijst gepubliceerd van alle Kriegsverluste; het Klooster in landschap stond op die lijst. Tot 1990 hoort of ziet niemand iets van het schilderij. Maar dan duikt het plotseling in Amsterdam op. Een zekere Cohen wendt zich tot het Rijksmuseum en vraagt inlichtingen over het schilderij. Hem wordt verteld dat het tijdens of vlak na de Tweede Wereldoorlog gestolen is en als zodanig gesignaleerd staat. Cohen gaat echter op 20 april 1990 naar het veilinghuis Christie's en biedt het schilderij ten verkoop aan. Als de catalogus van Christie's verschijnt, raakt het Land Sachsen gealarmeerd. Het legt op 21 mei 1991 revindicatoir beslag op het schilderij en met een beroep op zijn eigendomsrecht dagvaardt het Land Sachsen deze Cohen tot afgifte van het schilderij. Cohen stelt vervolgens dat hij het schilderij begin april 1990 in Nederland gekocht had van een zekere Gennadi Iljin, een verder ook aan Cohen onbekende Russische bokstrainer, afkomstig uit Rusland en in 1985 naar Finland geëmigreerd, die het schilderij gekocht zou hebben van een neef, die het via zijn moeder verworven zou hebben uit de nalatenschap van hun beider grootmoeder, die het schilderij al sinds de jaren vijftig boven de haard had hangen. Cohen zou het schilderij hebben gekocht voor een bedrag van $f 100.000$ en hij stelde zich op het standpunt dat in het licht van deze feiten de rechtsvordering van het Land Sachsen op grond van het bepaalde in art. $2004 \mathrm{BW}$ van 1838 verjaard was. ${ }^{27}$ Op het eerste gezicht lijkt het verweer van Cohen kansrijk. 35 jaar na de oorlog moet het maar eens afgelopen zijn met de onzekerheid omtrent de eigendom van alle mogelijke voorwerpen, ook al betreft het geroofde goederen. Rechtszekerheid gebiedt dat de op zichzelf duidelijke woorden van de wet serieus genomen

27. Art. 2004 BW luidde tot de invoering van het BW van 1992: 'Alle regtsvorderingen zoo wel de zakelijke als de persoonlijke, verjaren door dertig jaren, zonder dat hij die zich op verjaring beroept verpligt zij eenigen titel aan te toonen, of dat men hem eenige exceptie, uit zijne kwade trouw ontleend, kunne tegenwerpen.' In zijn arrest van 14 november 1969, NJ 1970/283 heeft de Hoge Raad uitgemaakt dat de verjaring begint te lopen wanneer een ander dan de eigenaar zich gaat gedragen als ware hij de eigenaar (letterlijk: bezitsdaden ten aanzien van de zaak heeft gesteld) In het BW van 1992 is deze extinctieve verjaringstermijn van dertig jaar teruggebracht tot twintig jaar, met dien verstande dat voor sommige milieudelicten een termijn van dertig jaar geldt. 
worden. De extinctieve verjaring slaat onherroepelijk toe na dertig en tegenwoordig reeds na twintig jaar, zo lijkt het.

Het Land Sachsen vond die conclusie (begrijpelijkerwijs) wel heel onbevredigend. Het wees er allereerst op dat naar Duits recht het leerstuk van de verjaring anders functioneert. Daar is het helemaal niet vanzelfsprekend dat opvolgende bezitters de tijd gedurende welke hun voorgangers bezeten hebben bij hun eigen tijd mogen optellen. Daarvoor is op zijn minst genomen noodzakelijke voorwaarde dat de rechtsverkrijger te goeder trouw is, en bij het dubieuze verhaal van Cohen kan men aan diens goede trouw gerede twijfelen. Maar in drie instanties oordeelde de Nederlandse rechter Duits recht op deze zaak niet toepasselijk. Het schilderij bevond zich in Nederland; het was in Nederland in beslag genomen en dus was Nederlands recht toepasselijk. Het Land Sachsen probeerde nog de stelling ingang te doen vinden dat het niet zo kon zijn dat het rechtsregime dat van toepassing is op een gestolen roerende zaak, wisselt op ieder moment dat het over een grens gesmokkeld wordt, maar deze reductio ad absurdum vond geen genade in de ogen van de rechterlijke colleges. Naar Nederlands recht was, althans vóór 1992, de termijn van de extinctieve verjaring dertig jaar na de diefstal voltooid. Dat was dus in 1975, eventueel een paar jaar later. Of Cohen in 1990 wel of niet te goeder trouw was, doet niet meer ter zake.

Het Land Sachsen lag ook nog voor een ander anker. Het betoogde met een beroep op tal van internationale verdragen, waaronder de hierna te noemen Inter-Allied Declaration against Acts of Dispossession committed in Territories under Enemy Occupation and Control, het Verdrag inzake de bescherming van culturele goederen in geval van een gewapend conflict van 1954 (bekend als 'Haagse Conventie'), het Unesco Verdrag van 1970 inzake de middelen om de onrechtmatige invoer, uitvoer of eigendomsoverdracht van culturele goederen te verhinderen, de Richtlijn van de Raad van de Europese Gemeenschappen van 15 maart 1993 (die inmiddels heeft geresulteerd in de invoering van een nieuw artikel in het BW: art. 3:86a) en het Unidroit Verdrag van 1995, dat in ons recht zo langzamerhand een systeem is binnengeslopen dat in overeenstemming met het Duitse voorbeeld de rechtsvordering van de eigenaar mogelijk moet maken, niettegenstaande de op het eerste gezicht in een andere richting wijzende bepaling van (destijds) art. 2004, thans art. 3:86 BW. Ook dat betoog werd verworpen. We waren destijds nog lang niet zover in Nederland dat terugvordering van oorlogsbuit anders moet worden beoordeeld dan terugvordering van anderszins gestolen goederen.

Ook het laatste anker waarvoor het Land Sachsen lag, bleek niet bestand tegen het zware weer. Fundamentele rechtsbeginselen van redelijkheid en billijkheid, zo had het Land betoogd, brengen met zich mee dat de extinctieve verjaringstermijn niet aanvangt of kan worden voltooid voordat de schuldeiser zijn vordering geldend kan maken. Als je werkelijk niet weet waar het schilderij zich bevindt, moet je dan lijdzaam toezien dat je rechtsvordering uitdooft? 'Ja', oordeelde de Hoge Raad. ${ }^{28}$

'Het bezwaar dat de eigenaar aldus zijn rechtsvordering kan verliezen voordat hij deze daadwerkelijk heeft kunnen instellen is niet doorslaggevend tegenover de eisen van rechtszekerheid in het rechtsverkeer die het instituut van de verjaring mede beoogt te dienen en die verlangen dat na het verstrijken van een vanaf een vast tijdstip lopende, vaste termijn de zaak niet meer kan worden opgeëist op grond van vóór de aanvang van die termijn bestaande feiten.'

\section{De Hoge Raad bevestigde daarmee bestaande rechtspraak. ${ }^{29}$}

Nederland is een paradijs voor kunstrovers, concludeerde een commentator. ${ }^{30}$ De Hoge Raad lijdt kennelijk aan een gebrek aan 'rechtspolitieke moed', schreef een ander. ${ }^{31}$ De enige mogelijkheid om tot een ander oordeel te komen ligt in anticipatie op het Unidroit Verdrag, schreef een derde, ${ }^{32}$ maar dat laatste ligt niet voor de hand. Ten eerste kent dit verdrag een van het geldende recht wel heel afwijkende regeling, ten tweede kent het geen terugwerkende kracht, en ten derde was het destijds nog allerminst zeker dat ons land dit verdrag daadwerkelijk zou ratificeren. ${ }^{33}$ Alleen R.J.Q. Klomp vroeg zich af of de beslissing werkelijk zo onjuist was, nu Cohen een zoon van het oude volk was: '[W] elke rechter zou anno 1998 een joodse bezitter willen opdragen een schilderij af te staan aan een besmet Duits museum?'34 Ik heb voor dit argument geen enkele waardering, reeds omdat het zich niet verdraagt met art. 1 van de Nederlandse Grondwet. De beslissing kan ook geheel anders uitvallen. Dat leert ons de vergelijking met de

28. HR 8 mei 1998, NJ 1999/44 m.nt. Th.M. de Boer, AA 1998, p. 888 m.nt. P. Vlas.

29. HR 3 november 1995, NJ 1998/380. Daarover L.P.W. van Vliet, Verjaring en kunstvoorwerpen, in M. Loth \& L.P.W. van Vliet (red.), Recht over tijd. Hoever reikt het privaatrecht in het verleden? (Preadviezen Nederlandse Vereniging voor Burgerlijk Recht), Zutphen: Uitgeverij Paris 2018, p. 102-103.

30. Brunner 1992, p. 45-53

31. P. Neleman, Thieves' Paradise Revisited, in: CHJB Brunner-Bundel, Deventer: Kluwer 1994, p. 293-302.

32. R.W. Polak, Terugvordering van cultuurgoederen, NbBW 1998, afl. 7/8, p. 84-86. Over de Unidroit Convention on Stolen or Illegally Exported Cultural Objects ook M.S. van Gaalen \& A.J. Verheij, De gevolgen van het Unidroit-Verdrag inzake gestolen of onrechtmatig uitgevoerde cultuurgoederen voor Nederland, NJB 1997, afl. 5, p. 193-201; F. Kuitenbrouwer, Roofkunst. Restitutie van cultuurobjecten met een dubieuze herkomst, NJB 2002, afl. 4, p. 169-175.

33. Dat is inmiddels op 28 juni 1996 geschied; nadien is art. 3:86b BW ingevoegd bij de Uitvoeringswet UNESCO-verdrag 1970 inzake onrechtmatige invoer, uitvoer of eigendomsoverdracht van cultuurgoederen, Stb. 2009, 255 (inwerkingtreding: 1 juli 2009).

34. R.J.Q. Klomp, Dieven met geduld, in: Tijd en onzekerheid (BW-krant Jaarboek 16), Deventer: Kluwer 2000, p. 59. 
hiervoor besproken, aan de common law ontleende zaken. ${ }^{35}$ Maar er is op het stuk van de verjaring zelfs nog meer aan de hand.

\subsection{Gemeente Heusden/Verweerders}

In de zaak die werd beslist met het arrest van de Hoge Raad van 24 februari 2017 was het volgende aan de hand. In februari 1973 hadden de eisers de eigendom verkregen van een stuk grond in Uden. Het perceel van de eisers grensde aan de zuidzijde aan een bosperceel, dat volgens de kadastrale gegevens eigendom van de gemeente was. Over dat bosperceel liep een pad naar een daarachter gelegen dijk, de Heidijk. Niet later dan 1980 hebben de grondeigenaren een stuk van het bosperceel omheind met een afrastering bestaande uit aluminium staanders met geplastificeerd gaas van 1,40 meter hoog met daarin een afsluitbaar hek. Zij hebben op het omheinde stuk een tweetal boshutten gebouwd en een jeu-de-boulesbaan en een houtopslag aangelegd. In januari 2003 kondigt de gemeente werkzaamheden aan de Heidijk aan en zegt zij in verband daarmee een door haar gestelde overeenkomst tot gebruik van de gemeentegrond op. Eisers ontkenden een dergelijke overeenkomst te zijn aangegaan en zij vorderden in rechte een verklaring voor recht dat zij op de voet van art. 3:105 jo. art. 3:306 BW het omheinde stuk grond door verjaring in eigendom hadden verkregen, en voorts een veroordeling van de gemeente tot medewerking aan de notariële vastlegging. De rechtbank wees die vordering af, oordelende dat het bezit van eisers onvoldoende kenbaar was geweest, maar het Gerechtshof's-Hertogenbosch heeft dat vonnis vernietigd en de vordering alsnog toegewezen. Naar het oordeel van het hof voldeed het bezit van eisers gedurende meer dan twintig jaar aan de vereisten van ondubbelzinnigheid en kenbaarheid. De Hoge Raad bevestigde op zijn beurt dat deze in het BW van 1838 (art. 1992) uitdrukkelijk als zodanig benoemde voorwaarden van 'ondubbelzinnigheid' en 'kenbaarheid' (en

35. Een in dit verband interessante dading, waarbij beide partijen (veel?) water bij de wijn deden, kwam tot stand tussen de Fondation Beyeler te Bazel en de zoon van de Russische schilder El Lissitzky, Jen. Het ging om het schilderij Improvisatie nr 10, een op 1910 gedateerd schilderij van Kandinsky. Jen Lissitzky heeft in een meer dan tien jaar durend gevecht teruggave van dit schilderij gevorderd. Voor de oorlog was het eigendom van zijn moeder, Sophie Küppers. Toen zij in 1927 met El Lissitzky trouwde, gaf zij haar collectie, waaronder dit schilderij, in bewaring bij een museum in Hannover. In 1937 werd die collectie door de nazi's geconfisqueerd. Het schilderij van Kandinsky, een van zijn eerste abstracte werken, werd tentoongesteld in München op een expositie van entartete Kunst. Ernst Beyeler kocht het schilderij in 1951 van een particuliere handelaar, naar eigen zeggen geheel te goeder trouw. Hij achtte de rechtsvordering van Jen verjaard. Jen beriep zich op algemene rechtsbeginselen en op het akkoord over de restitutie van oorlogskunst dat in 1998 bij de Holocaustconferentie in Washington was gesloten. De exacte voorwaarden van het compromis tussen beide partijen zijn niet bekendgemaakt; slechts is hier duidelijk dat het in het museum van de Fondation Beyeler zal blijven hangen. Inmiddels heeft echter de Duitse kunsthistoricus en speurder Clemens Toussaint beslag op het zo'n \$ 20 miljoen geschatte schilderij laten leggen, stellende dat hij met Jen Lissitzky had afgesproken dat hij (Toussaint) de helft van het overeengekomen bedrag bij een eventuele schikking zou krijgen voor zijn geleverde diensten en voorschotten op advocaatkosten en kosten voor langdurig, historisch ingewikkeld onderzoek. hun invulling) als criteria ook onder het nieuwe recht zijn blijven voortbestaan voor de beantwoording van de vraag of iemand bezit van een zaak heeft. Ook bevestigde de Hoge Raad zijn oudere rechtspraak dat het voor de ondubbelzinnigheid van 'bezit' niet uitmaakt of de oorspronkelijk eigenaar zonder of met vergaand onderzoek achter de inbezitneming kan komen:

'Een dergelijk niet dubbelzinnig bezit is aanwezig wanneer de bezitter zich zodanig gedraagt dat de eigenaar, tegen wie de verjaring loopt, daaruit niet anders kan afleiden dan dat de bezitter pretendeert eigenaar te zijn (HR 15 januari 1993, NJ 1993/178).' (r.o. 3.4.6)

Verder bevestigde de Hoge Raad dat het voor het bezit in beginsel niet uitmakt of het ook een huurder had kunnen zijn (of een andere gebruiksgerechtigde) die de daden had kunnen verrichten die de verjaringsverkrijger wenst aan te merken als specifieke bezitsdaden. Veeleer moet de oorspronkelijke eigenaar aantonen dat hij op objectieve gronden, zoals een overeenkomst, heeft kunnen aannemen dat de verjaringsverkrijger daadwerkelijk alleen maar gebruiksgerechtigde is geweest. $\mathrm{Nu}$ de gemeente dienaangaande geen feiten of omstandigheden heeft aangevoerd waaruit kon worden afgeleid dat zij mocht veronderstellen dat de (oorspronkelijk) eisers zich bij het gebruik van de omstreden strook grond niet als eigenaars beschouwden, maar op andere gronden meenden dat zij deze grond van de gemeente mochten gebruiken, zodat de eigendom van de gemeente geen gevaar liep (HR 26 februari 1915, W9864), lag bekrachtiging van het arrest van het hof voor de hand.

De Hoge Raad geeft vervolgens een overweging ten overvloede die onmiddellijk in de literatuur veel stof heeft doen opwaaien. Aan de eigendomsverkrijging op grond van art. 3:105 BW door een bezitter te kwader trouw ligt niet een afweging ten grondslag van de tegenover elkaar staande belangen van de rechthebbende en die bezitter, zoals dat wel het geval is bij de verjaring ten gunste van een bezitter te goeder trouw (art. 3:99 BW). Art. 3:105 BW is uitsluitend ingegeven door de wens van de wetgever dat, als geen vordering meer kan worden ingesteld om het bezit te beëindigen, de bezitter eigenaar wordt, ook al staat zijn goede trouw niet vast, maar (en dan komt het):

'[d]ie keuze van de wetgever laat evenwel onverlet dat de zojuist bedoelde partij bloot kan staan aan een vordering uit onrechtmatige daad van de (voormalige) rechthebbende die zijn eigendom aan die partij heeft verloren door de werking van art. 3:105 BW'.

Voor die stelling beroept de Hoge Raad zich dan op een op zijn minst genomen ongelukkige brief van de minister van Jus- 
titie aan de Tweede Kamer uit 2004, ${ }^{36}$ en hij verbindt daaraan de consequentie dat de vordering uit onrechtmatige daad kan strekken tot schadevergoeding in natura, bestaande in teruglevering van de door de werking van art. 3:105 BW in eigendom verkregen zaak. Overigens leidde al spoedig na dit arrest de Rechtbank Rotterdam uit het gebruik van het hulpwerkwoord kan in deze overweging af dat de Hoge Raad de hoofdregel, dat schadevergoeding in de vorm van geld geschiedt, niet heeft aangetast, en zij wees de vordering tot schadevergoeding in de vorm van teruglevering van de grond aan de gemeente af, nu die niet een (zwaarwegend) belang daarbij had aangetoond. ${ }^{37}$

De Rechtbank Noord-Holland wees in een vergelijkbare zaak de vordering tot (volledige) schadevergoeding op de voet van art. 6:103 BW, bestaande in teruglevering van het door verjaring verkregene, af omdat de gemeente wist van de inbreuk op haar eigendomsrechten, maar naliet daartegen op te treden. $\mathrm{Zij}$ merkte dit aan als een aan de gedepossedeerde eigenaar toerekenbare omstandigheid waarvan het verlies van eigendom (mede) het gevolg is. Daarmee ontbreekt het vereiste causale verband, of althans is sprake van eigen schuld aan de kant van de gemeente. Hierop stuitte naar het oordeel van de rechtbank toewijzing van de vordering tot schadevergoeding in de vorm van teruggave van de strook grond af. ${ }^{38}$ Het Gerechtshof Amsterdam dacht daar in appel echter geheel anders over: de eventuele kennis van een medewerker van de gemeente omtrent het gebruik dat gedaagden van de grond maakten, kan niet aan de gemeente worden toegerekend, omdat deze medewerker niet behoort tot het college van burgemeester en wethouders of een ander bestuursorgaan. Anders dan de rechtbank oordeelde het hof dat de gemeente dus geen eigen schuld kan worden tegengeworpen, noch de stelling dat causaal verband ontbreekt. De vordering van de gemeente Bergen tot veroordeling van de bezitters de door hen wederrechtelijk in bezit genomen strook grond aan de gemeente over te dragen, lag derhalve voor toewijzing gereed, omdat het hof dit een passende wijze van schadevergoeding achtte. ${ }^{39}$ Die vordering is overigens onderworpen aan de verjaringstermijn van art. 3:310 lid 1 BW, dus door verloop van vijf jaren na de aanvang van de dag, volgende op die waarop de gedepossedeerde eigenaar zowel met de schade als met de daarvoor aansprakelijke persoon bekend is geworden, en in ieder geval door verloop van twintig jaren na de gebeurtenis waardoor de schade is veroorzaakt.

In een vonnis van 14 november 2018 oordeelde de Rechtbank Limburg dat dit moment ten vroegste het moment van de

36. Aanhangsel Handelingen II 2004/05, nr. 332, geciteerd in r.o. 3.7.3. Over de vraag of aan deze brief enig gezag als rechtsbron toekomt: F.J.M. Verstijlen, De verjaring voorbij. Een verbintenisrechtelijke correctie op de goederenrechtelijke verkrijging van artikel 3:105 BW na HR 24 februari 2017, NJ 2018/141 (Gemeente Heusden/M.), NJB 2018/1698, afl. 32 , p. $2380-2386$, in par. 5 .

37. Rb. Rotterdam 19 juli 2017, ECLI:NL:RBROT:2017:9336, RVR 2018/13.

38. Rb. Noord-Holland 24 januari 2018, ECLI:NL:RBNHO:2018:512, RVR 2018/107.

39. Hof Amsterdam 30 juli 2019, ECLI:NL:GHAMS:2019:2817. verkrijgende verjaring is, dat wil zeggen: na voltooiing van een termijn van twintig jaar na aanvang van het bezit. ${ }^{40} \mathrm{Bij}$ datzelfde vonnis oordeelde de rechtbank ook dat het moment van verkrijgende verjaring als schadeveroorzakende gebeurtenis moet worden gezien, en niet, zoals Hoops en Verstappen eerder hadden het betoogd, ${ }^{41}$ het moment van inbezitneming door de occupant. Dat is op zijn minst genomen een controversiële beslissing, reeds omdat niet onmiddellijk valt in te zien dat aan het enkele intreden van de voltooiing van de verjaring op een door de wetgever bepaald tijdstip de kwalificatie van onrechtmatige daad zou moeten worden gehecht. Zou men bij wege van gedachte-experiment met de middeleeuwse beoefenaren van het canonieke recht willen aannemen dat het niet teruggeven van hetgeen aan een ander toekomt als strijdig met het achtste van de tien geboden ('gij zult niet stelen') onrechtmatig is, dan zou die onrechtmatigheid zich toch ook reeds voor de voltooiing van de verjaringstermijn voordoen. Iets moderner: de verkrijging van het eigendomsrecht door de bezitter na ommekomst van de verjaringstermijn is een creatie van de wetgever teneinde de anomalie van een eigendomsrecht zonder bijbehorende vordering (dominium sine re) te ontgaan, en die als onrechtmatig aan te merken heeft iets ongerijmds. Per slot van rekening zijn er niet veel schrijvers die ook bij de extinctieve verjaring van de vordering tot beëindiging van het bezit van een niet-rechthebbende (art. 3:314 BW) rekening wensen te houden met de mogelijkheid dat aan de daardoor veroorzaakte vermogensaanwas een zekere onrechtmatigheid kleeft (zodat daardoor zelfs de vordering uit ongerechtvaardigde verrijking in het zicht komt). ${ }^{42}$

Toch is er wel het een en ander vóór het standpunt van de Rechtbank Limburg te zeggen, ook uit systematisch oogpunt, naar D.F.H. Stein betoogde, ${ }^{43}$ maar de beslissing inzake de Gemeente Heusden/Verweerders blijkt bij nader toezien toch wel enige rafelrandjes te vertonen. ${ }^{44}$ De Rechtbank Amsterdam had eerder, bij vonnis van 1 november 2017, een vordering tot teruglevering van een kavel afgewezen, omdat de eiser in deze procedure pas na voltooiing van de verjaring eigenaar was geworden van het perceel waarvan de strook grond deel uitmaakte. Hij kwalificeert niet als gedepossedeerde eigenaar, omdat hij nooit eigenaar was geweest. Jegens hem kan noch de inbezitneming door de occupant, noch de voltooiing van de verjaringstermijn als onrechtmatig worden aangemerkt. Eiser is dus nimmer eigenaar geweest van de strook grond en kan levering daarvan niet opeisen. ${ }^{45}$ Niet lang tevo-

40. Rb. Limburg 14 november 2018, ECLI:NL:RBLIM:2018:10698, NJF 2019/36, BR 2019/11 m.nt. T.B. van Dijk en M. de Zoete.

41. B. Hoops \& L.C.A. Verstappen, Van 20 jaar naar 40 jaar. De Hoge Raad helpt eigenaars in de strijd tegen landjepik, WPNR 2017/7143, p. 256.

42. Van der Linden 2016, p. 296-299; A.G. Castermans in diens noot onder Gemeente Heusden/Verweerders, AA 2017, p. 522 en H.J. Snijders in diens noot onder dit arrest in NJ 2018/141, alsmede J.E. Jansen, Schadevergoeding uit onrechtmatige daad na verkrijging door art. 3:105 BW, RMThemis 2018, afl. 1, p. 9-10.

43. D.F.H. Stein, Verjaring van schadevergoedingsvorderingen bij voortdurende onrechtmatige daden, NTBR 2019/11, par. 5.3.2.

44. Verstijlen 2017.

45. Rb. Amsterdam 1 november 2017, ECLI:NL:RBAMS:2017:10319. 
ren had de Rechtbank Noord-Holland een vordering tot teruglevering van de grond afgewezen omdat in dat geval zelfs die vordering op grond van onrechtmatige daad door het verloop van twintig jaar sinds de voltooiing van de bevrijdende verjaring reeds was verjaard. ${ }^{46}$

Van een vordering uit onrechtmatige daad kan eenvoudigweg geen sprake zijn als de onrechtmatigheid ontbreekt, bijvoorbeeld wanneer de bezitsuitoefening door de occupant te goeder trouw is aangevangen en voortgezet, bijvoorbeeld omdat reeds zijn rechtsvoorganger dat ondubbelzinnig en openbaar deed. Een bezitter is te goeder trouw wanneer hij zich als rechthebbende beschouwt en zich redelijkerwijze ook als zodanig mocht beschouwen (art. 3:118 lid 1 BW). Goede trouw wordt vermoed aanwezig te zijn; het ontbreken van goede trouw moet worden bewezen (art. 3:118 lid 3 BW). ${ }^{47}$ Aldus ook de Rechtbank Noord-Holland in een vonnis van 30 mei 2018, ${ }^{48}$ evenals de Rechtbank Overijsel in een vonnis van 25 juli $2018 .^{49}$

\section{Paradijs voor dieven of een paradijs voor overjarige litiganten}

Een groot aantal vragen is met het voorgaande niet beslist. Vast staat echter wel dat met de hier besproken uitspraken andermaal is bevestigd dat de common law in het algemeen, en het recht van de staat New York in het bijzonder, aanzienlijk meer geneigd is de oorspronkelijke, gedepossedeerde eigenaar te beschermen tegen de actuele bezitter dan de civil law in het algemeen, en het Nederlandse recht in het bijzonder. ${ }^{50}$

Er zijn verschillende middelen die de common law bezigt ter verwerkelijking van dit rechtspolitieke doel, California kende aanvankelijk in $₫ 338$ (c) van het Civil Statute of Limitations de bepaling dat de vordering tot afgifte van personal property, respectievelijk tot schadevergoeding verjaarde na drie jaar, te rekenen vanaf de dag van het verlies van het goed of de beschadiging ervan, maar in 1983 werd deze bepaling vervangen door een die een discoverability test bevat, zodat de verjaringstermijn eerst aanvangt op de dag waarop de gedepossedeerde eigenaar weet (of redelijkerwijs had behoren te weten) dat hij een actie heeft en tegen wie hij die moet instellen. De onlangs ingevoer-

46. Rb. Noord-Holland 29 augustus 2018, ECLI:NL:RBNHO:2018:7555.

47. Hof Amsterdam 31 januari 2017, ECLI:NL:GHAMS:2017:264, RVR $2017 / 26$

48. Rb. Noord-Holland 30 mei 2018, ECLI:NL:RBNHO:2018:4430, NJF $2018 / 378$.

49. Rb. Overijssel 25 juli 2018, ECLI:NL:RBOVE:2018:2697, NJF $2018 / 480$.

50. Overigens kunnen niet alle common law-jurisdicties over één kam worden geschoren. Het recht van New Jersey stemt overeen met het Nederlandse recht doordat het na ommekomst van de verjaringstermijn de eigendom van het goed doet overgaan op de bezitter: '[T] he effect of the expiration of the statute of limitations, albeit on the theory of adverse possession, has been not only to bar an action for possession, but also to vest title in the possessor. There is no reason to change that result although the discovery rule has replaced adverse possession. History, reason, and common sense support the conclusion that the expiration of the statute of limitations bars the remedy to recover possession and also vests title in the possessor' (O'Keeffe v Snyder, 83 N.J. 478, 497 (N.J. 1980)). de federale Holocaust Expropriated Art Recovery Act van 2016 (HEAR) brengt daarin weinig verandering, behalve ten aanzien van de (aanzienlijk verlengde) verjaringstermijn. ${ }^{51}$

New York gaat echter aanzienlijk verder. Die staat laat de verjaringstermijn eerst aanvangen, nadat de gedepossedeerde eigenaar zijn goed heeft gelokaliseerd en afgifte daarvan heeft verzocht. Dat is de hierboven besproken demand-and-refusal rule. Hawkins e.a. hebben erop gewezen dat deze regel in zijn elementaire vorm de gewezen eigenaar de sterkst mogelijke positie geeft, met als gevaar dat New York verwordt tot een paradijs voor gewezen eigenaren die pogen van onder het stof opgedolven eigendomsrechten via de rechter in New York alsnog te verzilveren. ${ }^{52}$ Nederland, daartegenover, kent via het bepaalde in art. 3:86 en 3:105 BW een systeem waarin niet alleen de derde-verkrijger te goeder trouw, maar zelfs de dief zelf onder omstandigheden wordt beschermd tegen de gedepossedeerde eigenaar.

Tegenover elkaar staan aan de ene kant het Nederlandse systeem, dat ertoe leidt dat Amsterdam wordt aangezien als een paradijs voor kunstdieven, en aan de andere kant dat van $\mathrm{New}$ York, dat ertoe leidt dat die stad wordt aangezien als een paradijs voor overjarige litiganten. In de common law wordt het Nederlandse systeem zozeer afgekeurd, dat het zelfs zowel in Engeland als in de Verenigde Staten in strijd met de openbare orde wordt geoordeeld: Moses J en de Supreme Court lieten daar geen twijfel over bestaan.

In Nederland gaat de afkeuring van het systeem van de common law niet zover, dat daarvoor krachttermen als die van art. 3:40 BW worden gebruikt, integendeel. Nederland heeft zich aangesloten bij tal van verdragen op het gebied van de restitutie van oorlogsbuit, als daar zijn de Washington Principles on Nazi-Confiscated Art van december 1998, de Vilnius Forum Declaration van oktober 2000 en de Terezin Declaration van juni 2009, en in datzelfde kader het BW aangevuld met art. 3:86a en 3:86b. Minstens zo belangrijk is echter dat de Nederlandse Staat in geschillen met betrekking tot restitutie van ten gevolge van omstandigheden die rechtstreeks samenhangen met de Tweede Wereldoorlog voor betrokkenen verloren kunstvoorwerpen voor de Restitutiecommissie geen beroep op de regeling van de verjaring in het BW doet. Dat leidt tot de enigszins paradoxale situatie dat een claim die door een (rechtverkrijgende van een) slachtoffer van roof door de nazi's bij de burgerlijke rechter wordt ingesteld, wordt afgewezen indien de gedaagde een beroep op verjaring doet, terwijl een dergelijke claim tegen de Staat door de Restitutiecommissie wel wordt getoetst aan de in het Instellingsbesluit van die Commissie vermelde criteria. Men moet constateren dat zowel in het

51. Van Vliet 2018, p. 119-134.

52. Hawkins e.a. 1995, p. 61: 'New York is becoming a magnet for litigation of a variety of ancient claims as plaintiffs seek to extend its reasoning to matters having little or nothing to do with "stolen" art, including patrimony claims brought by foreign governments, claims for misplaced art and claims by heirs challenging the validity of the artist's original transaction.' 


\section{Maandblad \\ Vermogensrecht}

recht van New York als in het Nederlandse recht wordt gepoogd de allerscherpste kantjes van de tegenstelling af te slijpen.

In New York wordt uiteindelijk toch onaanvaardbaar geoordeeld dat de gedepossedeerde eigenaar ten koste van alles wordt beschermd tegen de opvolgende bezitter. Allereerst wordt het verweer van de kant van de bezitter tegen de vordering van de eigenaar dat deze zich in de afgelopen jaren onvoldoende heeft ingespannen om de verblijfplaats van de zaak te achterhalen teneinde die op te vorderen, het laches-verweer, tegenwoordig gemakkelijker gehonoreerd, zeker indien de eigenaar negligence valt te verwijten, namelijk dat de eigenaar de zaak te lang heeft laten rusten. De Belgische hoogleraar Bert Demarsin heeft er onlangs zelfs voor gepleit om dit verweer in zaken betreffende gedurende de Holocaust geroofde kunstvoorwerpen steeds te honoreren, maar dat pleidooi is vooralsnog aan dovemansoren gericht. ${ }^{53}$ Aan de andere kant moet ook worden toegegeven dat naarmate de koper lichtzinniger heeft toegegeven aan zijn begeerte naar het gekochte kunstwerk, hij des te minder bescherming behoort te genieten. Via een wederzijds aan te leggen due diligence test wordt ook gepoogd de allerscherpste kanten van deze demand-and-refusal-regeling af te slijpen. Zo mocht uiteindelijk Liz Taylor haar Vincent van Gogh behouden, ook al bestaat er aan gene zijde van de Atlantische Oceaan geen enkel begrip voor de Nederlandse beslissing dat Cohen zijn Jan van der Heyden niet hoefde af te geven aan de Gemäldegalerie te Dresden.

Aan de Nederlandse kant zien we sinds dat arrest ook een zekere poging tot toenadering. Door middel van zijn geruchtmakende arrest van 24 februari 2017 inzake de Gemeente Heusden/Verweerders heeft de Nederlandse Hoge Raad een stapje in de richting van de common law gezet. Het heeft er alle schijn van dat hij ongeveer de demand-and-refusal-regeling van het recht van New York heeft overgenomen: daar is immers van jegens de eigenaar onrechtmatig bezit (de tort of conversion) eerst sprake als de bezitter op het verzoek van de eigenaar tot restitutie heeft geweigerd daartoe over te gaan. Het is echter zeer de vraag of deze legal transplant een gelukkige is. Wij zagen hierboven al dat in Het Land Sachsen/Cohen de Hoge Raad oordeelde dat:

'[h] et bezwaar dat de eigenaar (...) zijn rechtsvordering kan verliezen voordat hij deze daadwerkelijk heeft kunnen instellen (...) niet doorslaggevend [is] tegenover de eisen van rechtszekerheid in het rechtsverkeer die het instituut van de verjaring mede beoogt te dienen en die verlangen dat na het verstrijken van een vanaf een vast tijdstip lopende, vaste termijn de zaak niet meer kan worden opgeëist op grond van vóór de aanvang van die termijn bestaande feiten'.

53. B. Demarsin, Has the Time (of Laches) Come? Recent Nazi-Era Art Litigation in the New York Forum, Buffalo Law Review (59) 2011, p. 621-692.
Dat was in lijn met eerdere rechtspraak. De demand-and-refusal-regeling legt echter de aanvang van de verjaringstermijn goeddeels in handen van de gedepossedeerde eigenaar en continueert dus de onzekerheid, zowel bij de verjaringsbezitter als bij het rechtsverkeer als geheel. Dat blijkt ook het geval te zijn in de hierboven geciteerde, lagere rechtspraak na het arrest van de Hoge Raad van 24 februari 2017 inzake de Gemeente Heusden/Verweerders. De gedepossedeerde eigenaar kan blijkens dat arrest in beginsel, niettegenstaande een geslaagd beroep op bevrijdende verjaring door de actuele bezitter en diens daarmee gepaard gaande eigendomsverkrijging, desalniettemin het voor hem verloren goed (de grond) alsnog terugvorderen, mits hij stelt en bewijst dat de bezitter de grond destijds te kwader trouw in bezit heeft genomen. Die vordering ontstaat op het moment dat de extinctieve verjaring is voltooid en pas dan gaat de verjaringstermijn voor die vordering lopen (art. 3:310 lid 1 BW). De vordering uit onrechtmatige daad kan een vordering tot teruglevering betreffen. Aldus lijkt de gedepossedeerde eigenaar niettegenstaande het bepaalde in art. 3:306 en 3:105 BW veertig jaar de tijd te hebben om zijn eigendom terug te eisen. Lijkt.

Hierboven is een aantal uitspraken vermeld waarin de vordering tot teruglevering van de voor de gedepossedeerde eigenaar verloren gegane grond werd afgewezen. ${ }^{54}$ De gemeenschappelijke noemer onder die afwijzingen lijkt te zijn dat die vordering tot teruglevering een vordering uit onrechtmatige daad moet zijn. Aan een bezitter te goeder trouw valt geen onrechtmatigheid te verwijten. Ergo: in zodanig geval is afwijzing van de vordering geboden. De vordering uit ongerechtvaardigde verrijking biedt evenmin soelaas. Niet valt vol te houden dat verkrijging door verjaring uit hoofde van art. 3:105 BW ongerechtvaardigd is in de zin van art. 6:212 BW. Dat geldt al in het algemeen, maar dat geldt a fortiori in geval van een verkrijging te goeder trouw. Aldus blijft de restitutie van door verjaring verkregen grond achterwege, niettegenstaande het obiter dictum in het arrest Gemeente Heusden/ Verweerders.

De kloof tussen de common law en de civil law die Davidson karakteriseerde met de uitspraak: 'A thief can't pass good title', blijft het resultaat van een verschillende afweging tussen het belang van de rechtszekerheid (civil law) en de individuele gerechtigheid (common law). In een tijd van toenemend handelsverkeer verdient die kloof nadere studie, want Gemeente Heusden/Verweerders laat te veel rafelranden. 